Sabira STÅHLBERg (Helsinki) \& Ingvar SVANBeRg (Uppsala)

\title{
Wild animals in Russian, Siberian and Central Asian households according to eighteenth-century travel reports
}

\begin{abstract}
Wild animals, such as mammals, birds and reptiles, have been kept in houses and nomadic tents for various purposes throughout historical times. At the same time, domestic animals such as horses and cattle have roamed freely in the forests and steppes of Russia, Siberia and Central Asia. In the late eighteenth century, European travellers explored the Russian Empire and kept wild animals in cages and baskets for scientific purposes. This comprehensive article discusses in detail the relationships between local peoples, scientists and wild and feral animals. Various functions of the animal resources are explored, especially the use of animals as tax payment, trade goods, food supply, pets and pest controllers, and for entertainment.
\end{abstract}

\section{Introduction}

During his extensive journeys in Russia and Siberia, the explorer Johan Peter Falck (1732-1774) observed a peculiar habit. Besides "ordinary" domestic animals, the local peoples kept various kinds of wild animals in their cottages and yurts. Hunters and herdsmen caught wild animals or brought home animal young and bird nestlings which became family pets. Some of these animals would end up as food or furs, while others lived for several years in human surroundings (cf. Svanberg 2001: 11-13). Falck noted also another interesting aspect of human-animal relationships among Central Asian and Siberian nomads: their domestic animals roamed freely. Horses, cattle, goats and sheep wandered on the steppe or in the taiga throughout the year with little attention from humans. Although not tame, the animals could nonetheless be defined as a kind of domestic animals, because humans claimed ownership over them and used them. Naturally, some of these free-roaming animals became feral (that is, they turned wild).

Customs of keeping free-roaming domestic animals and bringing wild animals into homes were common at least until the nineteenth century and still exist in some rural and nomadic areas. In the eighteenth century, these customs were very widespread in Russia, Siberia and Central Asia. They were recorded for the first time by European explorers of natural history around 1770. Among the first observers were Falck and two of his colleagues sent out by the Imperial Academy in St. Petersburg, Peter Simon Pallas (1741-1811) and Johann Gottlieb Georgi (17291802) (cf. Svanberg 1987).

During the reign of Catherine II, the Imperial Academy of Arts and Sciences in St. Petersburg launched several expeditions to explore the vast new areas of the Russian Empire. Western Siberia was conquered at the end of the sixteenth century, and over the following centuries Russia expanded to the Pacific Rim. The St. Petersburg 
Academy was founded by Peter I in 1724, following the model of European centres for higher learning. One of the most important sources for inspiration was the Prussian Academy of Sciences with its president, philosopher and mathematician Gottfried Leibniz (1646-1716), whose ideas deeply influenced the formation of the Russian Academy. During its first century, the Imperial Academy in St. Petersburg (later renamed several times) was dominated by Germans such as the mathematician Leonhard Euler (1707-1783), botanist Johann Georg Gmelin (1709-1755) and historian Gerhard Friedrich Müller (1705-1783). Other famous researchers included French astronomer and geographer Joseph-Nicolas Delisle (1688-1768) and the Dutch-Swiss family of mathematicians, Bernoulli. Only around the beginning of the nineteenth century did Russians come to constitute a majority in this international academy.

The Academy and its researchers represented the new European tendencies in science which grew in importance throughout the eighteenth century. Research generally developed towards an encyclopaedic science, which took interest in both humans and nature and emphasised the observation, exploration, documentation and classification of the natural environment, peoples, economy, languages, etc. In Russia, the government of the expanding empire required information about natural resources, demography and possibilities to open up new areas for e.g. agriculture and mining. Siberia was being heavily colonised by peasants, miners, criminals and exiles from Russia, settlers from Germany and Swedish prisoners of war. Little was known about the new regions and even less about the Central Asian nomads and other peoples who did not belong to the Russian Empire at this time. The government needed information in order to control the empire and its borders, the indigenous peoples and the economy.

Therefore, in order to map, explore and describe these regions the Academy was commissioned by Peter I and later monarchs to send out expeditions. Early explorers included the famous Danish seafarer Vitus Bering (1681-1741), who between 1725 and 1741 discovered Alaska and the Aleutian Islands, and German natural scientists Daniel Gottlieb Messerschmidt (1685-1735), who journeyed extensively through Siberia between 1720 and 1728, and Georg Wilhelm Steller (1709-1746), who researched flora and fauna around the Bering Strait.

These and all later expeditions show impressive and pioneering work. They laid the foundations for early North and Central Asian research, especially Siberian studies, and won international acclaim already during their first journeys. Several of the Academy researchers have achieved worldwide fame. Bering had geographical areas named after him and Pallas and Steller are still considered important figures in zoology and botany because of their many discoveries. The expeditions, studies and publications of the Academy continue to have a great impact on Russian and Asian studies today. They provide abundant materials for researchers in many fields from natural sciences such as hydrology, biology, mineralogy, meteorology and medicine, to human and social sciences such as linguistics, ethnology, economics and demography (about the Academy, see e.g. Osipov 1999). 
The expeditions relevant to our study started out in 1768-1769 and returned during the 1770s. Some of the explorers never came back, but their materials and travel journals found their way to St. Petersburg. The Academy explorers were interested in all natural and human-made materials they could find. They regularly sent boxes with findings, anything from mineral samples to dried plants and ethnographic objects back to St. Petersburg where their more settled academic colleagues analysed and carried out further observations and physical, chemical and other experiments on the samples. The expeditions were headed by an international team of prominent natural scientists: the German scholars Peter Simon Pallas, Samuel Gottlieb Gmelin (1744-1774) and Johann Anton Güldenstädt (1745-1781), Russian scholars Ivan Ivanovich Lepekhin (1740-1802) and Nikolai Petrovich Rychkov (1746-1784), and the Swedish scholar Johan Peter Falck. Johann Gottlieb Georgi first participated in Falck's expedition, but later was sent to work for Pallas (for further details see Berg 1954: 258-262).

Although descriptions of wild animals in homes and free-roaming domestic animals occupy only a small part of the work of the Academy explorers, the topic is important for the study of folk traditions, the economy and human-animal relationships. In all regions visited by the expeditions, local peoples and the explorers themselves had intense contact with wild or feral animals. The expeditions depended on horses and camels for transport and wild animals for observation and not least for food. However, the local peoples and the explorers had very different reasons for keeping wild animals. Peasants and nomads depended on wild or feral animals for their livelihood, but sometimes they also caught animals for entertainment or medicinal use. The explorers had a scientific goal and collected both live and dead animals during their journeys for further study. Small live animals were put in jars, cages or baskets and carried with the caravan. Some were killed later, dissected for scientific purposes and ultimately fed to other cage animals. Dead animals were prepared for conservation by the expedition assistants.

The animals kept in Russian, Siberian and Central Asian households mostly coincide with the animals transported in the travellers' cages and baskets, because the explorers often bought the animals from the locals. The explorers also bought hides of interesting animal species and hunted wild game when possible. Sometimes they performed experiments on the animals with chemical substances, different kinds of water (e.g. salt water or fresh water) or tried to cross-breed related species. In other cases, when for instance a certain animal was not present or difficult to obtain, the explorers interviewed local persons or migrants, such as Bukharan traders in Siberia, and noted all facts they could find including folk beliefs and customs. Complex research was carried out in order to describe the animals and compare them with already published material. If the animal was unknown, the aim was to describe and name the species (see Falck 1785: 9, 14; 1786: 449-450).

Although domestic or domesticated animals have had a close relationship with human society and have shared human dwellings since prehistoric times, very few studies to date have focused on this interaction (cf. Kruse 2002; Grier 2006). The phenomenon of keeping wild animals in households has not been studied previously 
in the case of Russia, Siberia and Central Asia as far as we know. There has been research on Europe and North America, as well as some other regions of the world for several decades now (see Moore 1937; Gunda 1969; Serpell 1989: 10-11; Svanberg 2007b; Way 2008; for non-Western examples, see Gilmore 1950; Layton 1991; Serpell 1996: 60-72; Erikson 2000; Drews 2001; Newsom \& Wing 2004: 204-208, Rea 2007: 52-57).

This article deals with two intertwined aspects of the relationship between humans and wild and feral animals. The first is animal-keeping among peasants and nomads in Russia, Siberia and Central Asia in the late eighteenth century, while the second is the habit of the scientific explorers to carry local wildlife as travel companions. Within this context we discuss also the animals that local amateur scientists and town dwellers possessed or studied. We must limit our study only to live animals that were present in households or carried with the expeditions. Hides and furs bought on the way, legends, concepts, folklore, myths, religious uses of animals, etc. are closely related to this topic and highly interesting, but will be only briefly touched upon. They require a separate study due to the great quantity of material.

\section{Purpose and Sources}

Wild animals in Russian and Siberian households, free-roaming Central Asian and Siberian animals and the explorers' animal companions are the focus of this ethnobiological study. Geographically it covers an area stretching from Moscow in the west to eastern Siberia and from the northern regions of Russia and Siberia south into Central Asia. We ask why domestic animals roamed freely and why certain wild animals were present in homes. Did they have an economic or a social function or both? Were they used as pest control or merely as pets? Ultimately the question is what the relationship between humans and animals was. The purpose of this study is to discuss the variety and reasons for the presence of wild and feral animals in households, the benefits and some costs. We view the relationship between humans and animals from different aspects in a pre-modern context, including not only peasant and nomad practices and concepts, but also the eighteenth-century scientists' relations and attitudes to animals and local peoples. In this way, the viewer (scientist) becomes also the viewed, which enables us to enlarge our source analysis.

Studies of human practices such as hunting, fishing and animal husbandry are part of the field of ethnobiology. Human concepts about animals, e.g. their place in the symbolic realm, also belong to this area of study. However, there have been few studies of wild animals as pets and helpers to humans, despite the fact that the keeping of animals is an ancient habit and known in most cultures. Even before the spread of agriculture, several kinds of animals accompanied humans and lived in or around human settlements. For instance, foxes and hedgehogs were supposedly kept by semisedentary hunters in Scandinavia about seven thousand years ago (cf. Brusewitz 2001; Jonsson 2001: 105; Serpell 1989: 10). 
As a general characteristic of human-animal relationships, researchers emphasise the human need for dominance. Affection for domestic and tame animals is inseparable from dominance (Yi 1984). Humans keep animals for their own use or amusement. It is the beauty, behaviour, songs or the commodities one can extract from the animal that matter. This dominance does not, however, only mean keeping animals in captivity and forcing them to adapt to human conditions and eat the food we offer. It comprises conscious breeding to create cultural forms which satisfy human nutritional, instrumental, aesthetic or other needs and wishes. Both economically useful domestic animals and animals kept for entertainment have been bred in this way (cf. Serpell 1989; Roth \& Merz 1996).

Historian Keith Thomas (1983) suggests several traits that distinguish companion animals from domestic animals. The latter are mainly kept for production (milk, meat, furs) and work (transport, pulling, ploughing, etc.) outside the living quarters of humans. Unlike domestic animals, companion animals are allowed into the house, spending nights and winters in relatively cosy and safe surroundings (from a human perspective). Humans are devoted to their care and food management. The livestock of farmers and nomads, which can be brought indoors in severe weather, never reach this degree of proximity and care. Another difference between domestic animals and companion animals is that the latter seldom end up as food. There are of course mixed forms, such as pigs that are kept as pets when small and then eaten when they become full-grown.

An important distinction must be made between domesticated animals and domesticates (Van Gelder 1969: 151). This is crucial, especially in the case of Russia, Siberia and Central Asia. Domesticated animals have been subjected for thousands of years to micro-evolutionary processes and cultural influences. They have changed genetically so that they differ to some degree from the original wild form and generally cannot survive without human help. Examples of such animals are cattle, dogs, horses and common sheep. Domesticates are wild animals that are brought into human settlements, such as birds, bear cubs, weasels and reptiles. Some reproduce in captivity over a few generations, but most domesticates are caught wild and must adapt to captivity. Many such animals do not prosper in human surroundings (Moore 1937).

As ethnobiologists analysing older data, we cannot pretend to be as precise and detailed as modern fieldworkers who personally gather information. The explorers of the Imperial Academy provide an additional filter which must be taken into account and we can only hope that our observers were somewhat accurate when gathering information. We must scrutinise how they gathered the data and why they chose to present some data and not others, and of course we also need to interpret their notes correctly. The material is fragmentary and scarce, often based on hearsay and second- or third-hand information which further complicates the analysis. Consequently, we apply source criticism and a comparative approach to the data, checking the validity, reliability and relevance of the information (cf. Ståhlberg 1996: 23; Svanberg 2000; Ståhlberg \& Svanberg 2006). 
Our main source is the three-volume publication of Johan Peter Falck's travel report which contains the most detailed descriptions of wild animals in homes and explorers' baskets. Falck was more interested in the topic of wild and feral animals than any of the other explorers and kept the largest travelling zoo in his expedition. The reason for this interest lies very probably in his Linnean education. Falck was born in 1732 in Broddetorp, Västergötland in southern Sweden and came to Uppsala University in 1751 . There he began to study medicine, but soon became a pupil of the famous natural scientist Carl Linnaeus and also worked as a private tutor to Linnaeus' son. In 1760, Falck intended to travel with his colleague Peter Forsskål (born in Helsinki in 1732) to Arab countries, but he was refused participation by the Danish government. Forsskål's expedition reached its goal, but most of its members died within a few years, including Forsskål himself (1763). Falck returned to Uppsala where he defended his thesis on botany in 1762 .

Being poor and receiving no financial support from his family, Falck had to find work after graduating. Linnaeus recommended him to colleagues in Russia, and in 1763 Falck travelled to St. Petersburg to take up a position as curator of a private natural history cabinet. Later he taught medicine and botany at the Collegium Medicum. When the Imperial Academy planned a new set of expeditions in 1768, Falck was recommended by colleagues and appointed leader of one of the so-called Orenburg expeditions, which departed for Moscow in September of the same year. During the next few years Falck and his team, including Johann Georgi, assistants, students and military escort travelled in the south Volga area, southern Urals, parts of the Kazakh steppe and western Siberia. In March 1774, Falck committed suicide in Kazan after a long illness. His travel report was published in 1785-1786 by Georgi.

When analysing the materials, one must consider that Falck and Georgi were students of Linnaeus. Their particular training explains the differences in attitude, structure, questions asked and working methods compared to other travel reports. Linnaeus provided his students with questionnaires and this also inspired the Imperial Academy's agenda, but only Falck and Georgi kept strictly to Linnaeus' programme.

Here we also find the answer to why Falck was so keen on carrying wild animals around for thousands of kilometres. He studied the animals and their feeding, sleeping and other habits on the road. Perhaps he also wanted to bring the animals back to St. Petersburg for the use of the Academy. He had the task of providing material for scientific purposes and regularly sent live animals and taxidermic (mostly stuffed) specimens to the Academy. He naturally also wanted to create a menagerie of his own for further study of the animals. Carl Linnaeus had kept several species of animals and birds in his so-called vivarium at the Academic Garden in Uppsala since the late 1750s. His collection included monkeys, raccoons, guinea-pigs, agouti, parrots, peacocks, a curassow and spoonbills. Linnaeus was very fond of watching and studying caged animals and wrote extensively about his observations. He also taught his students various methods of keeping wild animals and studying them (Linnaeus 1740, 1754a, 1754b, 1768; Svanberg 2007a). 
Although the Academy banned export of all scientific materials (with limited success, as Pallas for instance traded in rare goods from Siberia), it is possible that Falck wished to send at least some of the animals to Linnaeus. When Falck left for Russia, Linnaeus presented a list of plants and animals he wished to obtain, among them a wolverine (Gulo gulo). All students of Linnaeus received such lists when leaving Sweden and several were indeed able to provide their teacher with materials for observation (Broberg 1971). They gathered live animals and sent or travelled back with them to Uppsala. When Linnaeus received a gift he was usually grateful, but only if it was exotic and in some way useful to him. Falck's Finnish colleague Pehr Kalm (1715-1779) brought wild animals back from North America in 1751, but Linnaeus declined that gift; probably these animals did not interest him sufficiently. The opossum, some guinea-pigs and a turtle travelled with Kalm to Turku when he was installed there as a professor. The nocturnal opossum used to disturb his sleep, running around the room at night. Pehr Osbeck (1723-1805) tried in vain to bring back various animals from China, including a small parrot (Osbeck 1757: 101). Clas Alströmer (1736-1794) sent birds from Spain, and Pehr af Bjerkén (1731-1774) sent goldfish from England to Uppsala. Carl Peter Thunberg (1743-1828) was asked to bring birds from Southeast Asia, but none of his animals survived the long trip (Svanberg 2007: 40-41, 76). The tradition did not end with the death of Linnaeus: Carl Fredrik Hornstedt (1758-1809) tried unsuccessfully to bring apes, parrots, squirrels and turtles with him from Java, possibly as an intended gift or scientific contribution to Carl Peter Thunberg, who succeeded Linnaeus as professor in Uppsala (Hornstedt 2008: 278).

We have used as much as possible the modern scientific names for the species mentioned in order to facilitate identification of the animals, but the local plant or animal names noted by Falck are unchanged. For several reasons we also retain the eighteenth-century names of regions and peoples, indicating the modern ethnic name in brackets when possible. In the first case, Bukhara, Khiva, the Kazakh and Kalmyk Hordes were independent or semi-independent states at the time. Bukhara and Khiva make up most of present Uzbekistan. The Kazakh steppe belongs to Kazakhstan and the Kalmyk live mainly in Kalmykia, a republic within the Russian Federation. The present borders, however, differ greatly from their state in the eighteenth century.

In the second case, the peoples cannot always be identified precisely. The greatest difficulty is provided by the term Tatar. Today Tatar is an ethnonym, used for Volga or Kazan Tatars, Crimean Tatars, etc., but in the eighteenth century "Tatar" signified more or less any Turkic-speaking person in Russia and Siberia, Muslim or pagan, except Bashkirs and a few others who are mentioned by specific names. Tatars were usually designated and identified by their geographical position or a local name in addition to the generic "Tatar". This creates a confusion which we have attempted to solve by providing modern identifications in brackets, but in some cases it is impossible and we have left the term Tatar as it occurs in the sources, in the general meaning of 'Turkic-speaker'. 


\section{Free-roaming animals}

The most important animal in Central Asia and northern Eurasia is undoubtedly the horse (Equus caballus) (cf. Sinor 1972). Enormous herds of wild and feral horses still roamed the steppes and forests in the $1700 \mathrm{~s}$, but their numbers decreased greatly in the following century. The main reason for this was probably increasing colonisation, which limited the habitats of the horses. Today none of the original wild horses are left and only feral and free-roaming horses are present in Central Asia.

The Academy explorers singled out the Kazakh and Dzhungarian steppes (now broadly Kazakhstan and northern Xinjiang), the $\mathrm{Ob}$ area and the Baraba steppe in western Siberia as the main regions for wild and feral horses around 1770. Georgi noted (1799: 1024-1025) that the best animal breeders were the Kachin, Baraba and other Tatar [Siberian Turkic] groups. He notes also that these Turkic peoples owned not only horses but also all the domestic animals that Russians kept (cattle, pigs, dogs, cats, poultry, geese, ducks, etc., see Falck 1785: 155). The only exceptions were pigs and dogs among Muslims due to dietary and religious considerations. There was a difference, however. Russian peasants kept their animals near the settlements and cared intensely for them. Non-Russian peasants and nomads such as the Mongol, Buryat, Kalmyk, Kazakh, Bashkir, Nogai, Kachin, Barabin, Horse Tungus (southern Evenki) and many Caucasian peoples let not only their horses, but also sheep, goats and cattle wander freely throughout the year (Georgi 1799: 1078; 1800: 1474). The free-roaming, or as Falck (1786: 289-290) calls them, "half-wild" horses, satisfied most of the local peoples' needs. Food and drink such as meat, milk, cheese and kumys (fermented mare's milk), hides, clothes, sinew for sewing and other materials came from the horses. The local peoples would also ride and keep horses as draught animals.

Although humans claimed ownership and used the free-roaming horses in different ways, they did little for the welfare of the animals. The products and benefits from horses required almost no effort. Bashkirs, according to explorer Peter Simon Pallas (1773: 76), never made any hay for the winter "due to their inborn laziness". Georgi (1799: 1025) observes that some nomads made hay only for the basic survival of the animals in winter or for emergency situations. Apparently there was enough food available in the environment that horses could roam freely even during the cold season. Naturally many horses died of hunger and cold or were consumed by predators, but because of the great number of horses, these losses had little significance. The horses generally guaranteed their own safety. One chief stallion protected each herd, raised an alarm when danger approached and was reported to bravely fight wolves and other predators (Falck 1786: 289-290).

The reasons for leaving horses to roam freely can be found in the local economy and living conditions. Few peoples, especially nomads, had the ability to keep such great herds under a roof. This hands-off tradition of animal herding originated probably from the adaptation of humans to existing natural and economic conditions in which the abundance of horses was an important element. The attitude of respect and admiration towards horses and their freedom - which exists among all nomad 
peoples with horses - certainly played a role as well, but an educated guess would be that it followed such an adaptation. The same hands-off attitude existed also for other animals. Despite annual losses, the nomads profited greatly from their free-roaming animals. Although it seemed to the explorers that they were completely indifferent about their ownership, Nogai, Kazakh, Kalmyk and different Siberian nomads did pay attention to their horses. In order to secure the growth of their herds and advance economic interests, they killed only stallions and cared for weak foals in wintertime (Georgi 1800: 1658; Pallas 1773: 641-642). On the other hand, Falck (1786: 289290) noted that care was not important. Russian peasant horses in Siberia were in the same rugged condition as the nomad horses, despite differences in physical structure and the more intense care they received. The nomad horses were not as beautiful as European horses, but they were lively (an important characteristic in the eighteenth century), endured harsh conditions and did not need much human attention or good fodder to thrive. Thus, leaving the animals to roam freely was a better economic and labour investment than keeping them at home. Falck even recommended a transfer of the practice to other areas and species of animals (e.g. yaks, see below).

A close relative of the half-domesticated or feral horse was the actual wild horse (cf. Grubb 2005: 630-631). Falck did not observe a tarpan (Equus ferus ferus) himself, but his assistant Christoph Bardanes saw tarpan groups daily during his journey through the Kazakh steppe. Falck's colleague Samuel Gmelin even received a wild horse as a gift (Falck 1786: 290-291; Gmelin 1770: 415). Johann Schiltberger (1879: 139), who served as a slave-soldier to several Mongol and Turkish chiefs, is believed to have observed wild horses already in the fifteenth century. The tarpan is usually regarded as the last remnant of the herds of wild horses that once roamed the Eurasian forest and steppe landscapes. It is now extinct. Another wild relative is Przewalsky's horse (Equus ferus przewalskii) which was not acknowledged and described in detail until the 1870s. Explorer Nikolay Przewalsky's (Przhewal'skii 1876: 249-250) name is now used for this last surviving wild horse. Wild Przewalsky's horses no longer exist. The herds in Mongolia today belong to a programme that returns horses from captivity to their natural environment.

The Kazakhs held the view that the tarpans, locally known as taga, were in fact not originally wild, but feral horses. A legend tells of an old man named Boyan Bay, who roamed with his horses and turned wild himself. After he died, the herd became the ancestors of the wild horse. Falck and Pallas also were of the opinion that the wild horses were not a separate subspecies, but originated from feral and runaway horses. Falck noted that the herds of the Kazakhs and other nomads were so large that horses could easily run away without being noticed (Falck 1786: 291; Pallas 1776: 510-511). It is difficult to know today which explanation is correct, wild or feral, as tarpans no longer exist and the situation and numbers of horses are very different. Tarpans roamed the open areas in small groups of five or more horses. Their main habitats were the Kuban and Kipchak steppes (southern Russia), Kalmyk areas and the Baraba steppe in western Siberia. Falck (1786: 291) was told that wild horses were previously very common in Baraba, but because of an epidemic they almost died out together 
with a majority of the free-roaming horses of the Barabin Tatars. In the Kazakh and Dzhungarian steppes, tarpans could be seen in larger groups of up to twenty horses. Pallas (1771: 272) saw huge herds of wild horses and wild asses, sometimes mixed, in the Southern Ural. The Kazakhs would organise wild horse hunts (tarpan meat was a great delicacy), but they were seldom successful, as the tarpan was too quick. The Tatars chased wild horses around Samara, often shooting a stallion which had been lured by a mare tied to a tree (Falck 1786: 291; Pallas 1771: 211).

Local people tried to domesticate wild horses without success. Wild horses could not be kept at home or left in the steppe or forest with the free-roaming horses. Informants told Falck that all efforts to tame them were in vain. The wild horses would starve to death in captivity or flee at the first opportunity. At the RussianKazakh border, guards caught a tarpan foal which was "very wild". Pallas (1771: 272), who saw the foal, was later informed that the young stallion had fled and led some mares away. Tarpan stallions would sometimes "kidnap" mares which became feral and never returned to their herds. This, according to Georgi (1800: 1660), contributed to the survival of the species, which otherwise would have died out because of frequent hunting. Pallas (1776: 510-511) noted that if a very young foal was successfully tamed, it was stronger than ordinary horses. He also observed (1776: 175) wild horses used as draught animals among the Buryat.

The Asian wild ass (Equus hemionus), known in Kazakh and Kalmyk as kulan, is a small, strong and swift animal. It was never seen by Falck personally, but according to his informants, it lived in the Kazakh steppe and in even greater numbers in the Dzhungarian steppe, Bukhara and south towards Afghanistan and Persia (Falck 1786: 291-292). It ran faster than a horse and looked like a cross between a donkey and the Mongolian ass called dschiggetei 'long ear' (Pallas 1776: 217-219, 511-512). The Mongolian "long-eared" donkey is defined as Equus hemionus by Georgi (1800: 1662), but it probably refers to the subspecies Equus hemionus luteus (cf. Clark \& Duncan 1992; Grubb 2005: 632). This donkey, in contrast to the wild ass, was said to be easy to tame, ride and use as a draught animal. When tame, it would return by itself to human settlements. The only trouble was the animal's obstinacy. According to Georgi, it could halt and stand still "like a rock" until its mood changed and it decided to move forward again.

The kulan had many characteristics in common with the wild horse. Asses stayed together in herds of between ten and fifty. The strongest stallion was the leader and fought other stallions for supremacy. In the summer, the wild asses moved to the Aral, Balkhash and other lakes in the desert and fed on saxaul bushes (Haloxylon ammodendron). The kulan was not phlegmatic and easy-going like the domestic donkey, but savage and avoided humans. Local peoples caught it by chasing it into deep sand where it got stuck. The meat was considered a delicacy, especially among nomads, and hides were used for leather or sold as cold-weather clothes in Tashkent. Young foals were according to Falck (1786: 292) easily tamed and could be kept like domestic donkeys, but older animals never adjusted to living with humans. A contradictory piece of information was provided to Pallas (1776: 219) by a Cossack who 
tried to keep a foal. The young wild ass was impossible to tame and later the explorer was told that this foal had killed itself by jumping from a height. Both versions show that there were domestic donkeys to which sometimes wild asses were added.

Domesticated camels, one-humped (Camelus dromedarius) and two-humped (Camelus bactrianus), were common in the southern Siberian steppes and Central Asia. They were fewer in number than horses, but very important to Mongol, Kalmyk and Kazakh nomads (cf. Menges 1935 for Kazakh camel taxonomy). The wild and feral dromedary (one-hump camel) roamed the Dzhungarian and Kazakh steppes, the Ili area and the Siberian-Mongolian border (Falck 1786: 292-293). Already in the eighteenth century there were not many wild camels left and today there are practically only feral camels in Mongolia and Xinjiang (Hare 1997). Like the wild asses, camels were chased into an area where they got stuck. They were killed for meat and hides which were often sold to Tashkent. The young camels were tamed, but remained wilder than their relatives born in human settlements. Food, milk and wool were taken from camels and they were also used as load and draught animals (Georgi 1800: 1604-1606). Camels were not as abundant as horses or sheep, thus among many peoples the ownership of this costly animal gave prestige and the camels were treated with more care than horses. Rich Bashkirs allowed their two-humped camels, called tya, to roam freely during winter, but used to cover them with a felt coat to protect them from the cold (Falck 1786: 529). Kazakhs tied a piece of fabric over the genitals of female camels after conception so that the males would not disturb them any more. They also castrated male camels in order to keep peace in the herds. Camel males could otherwise be very aggressive (Falck 1786: 544; compare with goats below).

Reindeer (Rangifer tarandus) roamed freely in the Arctic and eastern Siberia, but humans claimed ownership over the herds. Reindeer-herding is well-known and still practised and need not be detailed here (cf. Lindin \& Svanberg 1986; Nellemann 1961). Georgi noted that the Saami, northern Finns and Tungus (referring to several peoples in eastern Siberia), Koryak, Chukchi and others kept reindeer in the eighteenth century. The Siberian peoples received hides, food and drink (blood), thread for sewing and many other products from the reindeer, and used them as draught animals and beasts of burden (Georgi 1776: 5, 17; 1799: 1079; 1800: 1612-4).

The domestic (Bos grunniens) and wild yak (B. mutus) or "Tangut cattle" as they were called previously, are found today mainly in Tibet and Mongolia, but in the eighteenth century there were wild yaks in great amounts also in the Tianshan and other mountains bordering China, in the state of Bukhara and the Kalmyk areas (cf. Bonnemaire 1984). The wild yak calves were, according to Falck (1786: 293-294), easily tamed and kept with other cattle and they did not run away once domesticated. The yaks were used for their delicious meat, fat and milk. Inspired by Linnaean ideas of economic benefit, Falck suggested that the yak could become a free-roaming domestic animal on the Terek and Don and in other parts of southern Russia.

Crucial for the economy and subsistence of both nomads and peasants were sheep. These roamed freely like the horses and were cared for only incidentally (Pallas 1771: 114; Georgi 1800: 1627-1628). For Kalmyks, Kazakhs, Nogai and Barabin Tatars, 
Mongols, Bashkirs and Bukharans sheep meant survival, materials, food and prosperity. Pallas (1771: 234) mentions that Kazakh merchants brought 40,000-60,000 sheep and tens of thousands of horses to Russian border markets every summer. The sheep were mostly domesticated common sheep (Ovies aries), but there were also several of the distinctive fat-tailed breed.

The wild sheep, or argali (Ovis ammon), existed in the steppe but was more common in the mountains. Falck's assistant Bardanes saw many wild sheep on the border between Russia and China. The argali was described as larger than the Kazakh fat-tailed sheep and more similar to wild goats. Falck was told (1786: 294) that it jumps from cliff to cliff and falls from the heights on its horns, landing unscathed. The wild sheep was so wild that it could be caught only with great difficulty. The lambs could be tamed if young enough, according to Pallas (1776: 232). Georgi (1800: 1637) contradicts this, claiming that argali do not eat and eventually die of hunger in captivity (compare similar stories above). Falck was told that the governor of Tobolsk tried to send a few wild sheep to St. Petersburg, but they all died on the way. The wild sheep was almost extinct around 1770 because of heavy hunting by the Kazakhs, who were keen to obtain its hide due to its value as a prestige symbol (Falck 1786: 294). Domestic sheep still remain the most important animal in Central Asia, although populations and herd sizes have decreased since the days of the explorers.

Finally goats (Capra aegagrus hircus) should be mentioned. They wandered together with the other "half-wild" animals but destroyed forests and gardens by feeding on everything. Many became feral and disappeared forever from human surroundings (Georgi 1800: 1619-1620). This piece of information would indicate that goats were usually kept near settlements. The Kazakhs used to tie bits of textiles on both rams and he-goats in order to keep them from mating early, delaying the birth of the lambs and kids until warmer weather in spring and thus securing the survival of the next generation of animals (Falck 1786: 545-546).

\section{Pets and fur animals}

In almost all cultures, people keep dogs as pets, protective animals and helpers in hunting (cf. Kroeber 1941; Serpell 1989: 10; Clutton-Brock 1999: 49-60). Many Kazakhs used to hunt with dogs, especially with a kind of greyhound which Falck identified, following Linnaeus, as a Canis grajus (or graius, Falck 1786: 546). Siberian domestic dogs (Canis familiaris) were used to keep guard and as work animals and also for transportation such as pulling sleighs. However, they were more or less wild and could easily become feral in areas with little human habitation. Many dogs were said to be of mixed heritage. Georgi (1800: 1500-1502) identifies a specific Canis sibiricus, which in his opinion was a breed that included wolf and feral dog ancestry. This dog was common in eastern Siberia, among the Russians and Tatars around Tobolsk, the Cheremiss (Mari), the Votyak (Udmurt) and several nomadic peoples. In summer, these dogs would become very wild because of their diet of predominantly fresh meat 
and fish. They had to be kept busy with hunting or else they would attack other domestic animals and even people. In the winter, the dogs had a less fresh diet, became more sedate and were not as dangerous. An unidentifiable subspecies called "steppe wolf" by Georgi (1800: 1507) was said to be very similar to the dogs of the Kamchadal (Itelmen) and other Siberian peoples, as well as the dogs kept by Siberian Russians.

Wild relatives of the dog were caught and domesticated in several areas. For instance the golden jackal (Canis aureus) was tamed like a dog in the Caucasus Mountains, Terek, Bukhara and by the Azeri (Georgi 1800: 1510). Dogs were not, however, kept only as protectors or draught animals. Throughout Siberia and Russia, dog furs were sold for several centuries together with many other kinds of furs and hides. The Siberian and Central Asian fur trade was famous already in medieval times. During the eighteenth century furs and hides were collected as tax from many nonRussian peoples (cf. Martin 2004).

Typical for Siberia is the combination of pet and fur animal. Few animals were kept only as pets in the sense that we keep pets today. Most animals had a function such as providing furs or food or controlling vermin populations. Among the dog's relatives, wolf (Canis lupus) cubs were taken when very young and kept in homes like dog puppies. When grown, they were killed for their furs (Pallas 1773: 203). The fox (Vulpes vulpes), which occurs in most of Eurasia, was another popular pet and fur animal. Besides hunting foxes and selling the fur like all other peoples in Siberia, the Ostyak (probably Khanty, possibly Selkup) men used to collect the young in spring, tame them and let the women feed the fox babies at their breasts. A few days before butchering the already grown foxes, the men would break the legs of the animals. The pain caused the foxes to stop eating and they lost weight quickly. This gave a better fur with less fat on the inside, which saved time in preparing the hide and made it more valuable (Falck 1786: 324; Georgi 1800: 1513).

Rodents were a hugely popular group of pet and fur animals in Russia and Siberia. They were often kept as pets for amusement, similar to how we keep guineapigs and hamsters today, but in the end they provided furs. Instead of living outside like the free-roaming animals or dogs, they shared human dwellings. Squirrels were especially great favourites. The long-tailed ground squirrel (Spermophilus undulatus), which occurs in the southern regions of Siberia and Russia, was kept in many houses. Falck (1786: 304-305) thought it was a mouse and kept a couple in a cage with water mice and pearl mice to see if they would reproduce. They did not. Although the genetic experiment failed, their value as entertainment remained great. "It is a lively creature, easily tamed and eats out of one's hand," Falck wrote enthusiastically. The males gnawed on wood like rats. When the cold set in, their sleep was so deep that the researcher could open their eyes or even break their legs without any reaction from the animals. When placed in a warm environment, they started eating and fell asleep again with full cheeks. In warm cottages the squirrels were awake all winter, but remained sluggish and almost looked ill. In Falck's cage the animals were fed with vegetables and reproduced, but all the young died. He sent some adult squirrels to St. Petersburg and they reached the Academy alive (cf. Georgi 1800: 1583). 
Other common pet and fur animals were small predators of the Mustelidae family. Today martens of different kinds can still be found as pets in Eastern Europe, including the Balkans, Russia and Ukraine. For instance, the stone marten (Martes foina) was caught and kept as a pet, but it was like a squirrel, quick and wild and ran away as soon as it had a chance (Georgi 1800: 1530). The weasel (Mustela nivalis) was a common visitor in and around houses and yurts. Especially in winter it sought human company because of the warmth that settlements provided (Georgi 1800: 1541). The weasel was caught for its fur, kept in a cage and fed with meat, mice, birds and other animal products. It lived for a long time and reproduced in captivity, but it could not be tamed. Weasel furs were often sold as fake stoat or ermine (Mustela erminea), although their real price was only half that of stoat fur (Falck 1786: 318).

Falck (1786: 311) had a couple of striped eastern chipmunks (Tamias striatus, Fig. 1) which were very beautiful but sensitive to weather. According to popular belief in Siberia, the chipmunk whistled when rain was coming. The chipmunks followed the Falck expedition for a couple of years and were fed with seeds and cedar nuts (actually from Swiss stone pine, Pinus cembra). They were very easy to keep and reproduced quickly. The chipmunks that Falck sent to the Academy arrived in St. Petersburg without any difficulties. Georgi (1800: 1589-1590) noted that even old chipmunks could be tamed and were often kept by local peoples in Siberia. However, chipmunks gnawed on the house and clothes and disappeared if not watched. Pallas (1773: 209) adds that chipmunks were mostly caught young, but they did not live long in captivity. Like squirrels and weasels, they were popular as pets because of their furs.

The most famous Siberian fur animal is certainly sable (Martes zibellina). It has been extensively hunted for its fine coat for centuries and is now almost extinct. The furs were sold throughout Asia and Europe in great quantities already in medieval times, but today the furs have become expensive luxury goods. Sable was a common household animal in Siberia in the eighteenth century. The sable could, according to Pallas (1773: 209), be kept at home if it was captured very young, but old sables would not adapt. Georgi (1800: 1534) noted that while the sable could be tamed, it was not very easy to keep. It hunted mice, an activity which was considered positive for human inhabitants who shared the house, but it also attacked household birds, fought constantly with the cats, smelled bad and slept most of the day, being active and disturbing human sleep during the night.

The steppe marmot (Marmota bobak) was common in an area extending from the Oka and Don Rivers in Russia to western China. It was sympathetic, easily domesticated and not difficult to keep. It fed on all kinds of rubbish of vegetable origin, bread, grain, etc. Around 1770, a sack of marmot furs gave a solid profit of 2-3 Russian roubles in Orenburg. The Kazakhs shot them with arrows, but otherwise marmots were hunted with snares or by filling their nests with water. In the winter, pet marmots slept in a cool place inside the houses. If they were moved into a warm room, they remained sleepy and did not eat much. Besides the dirt and smell, the European explorers noted that they gnawed on things in the house, including furniture and clothes, but it seems that local peoples did not mind, as marmots were very 


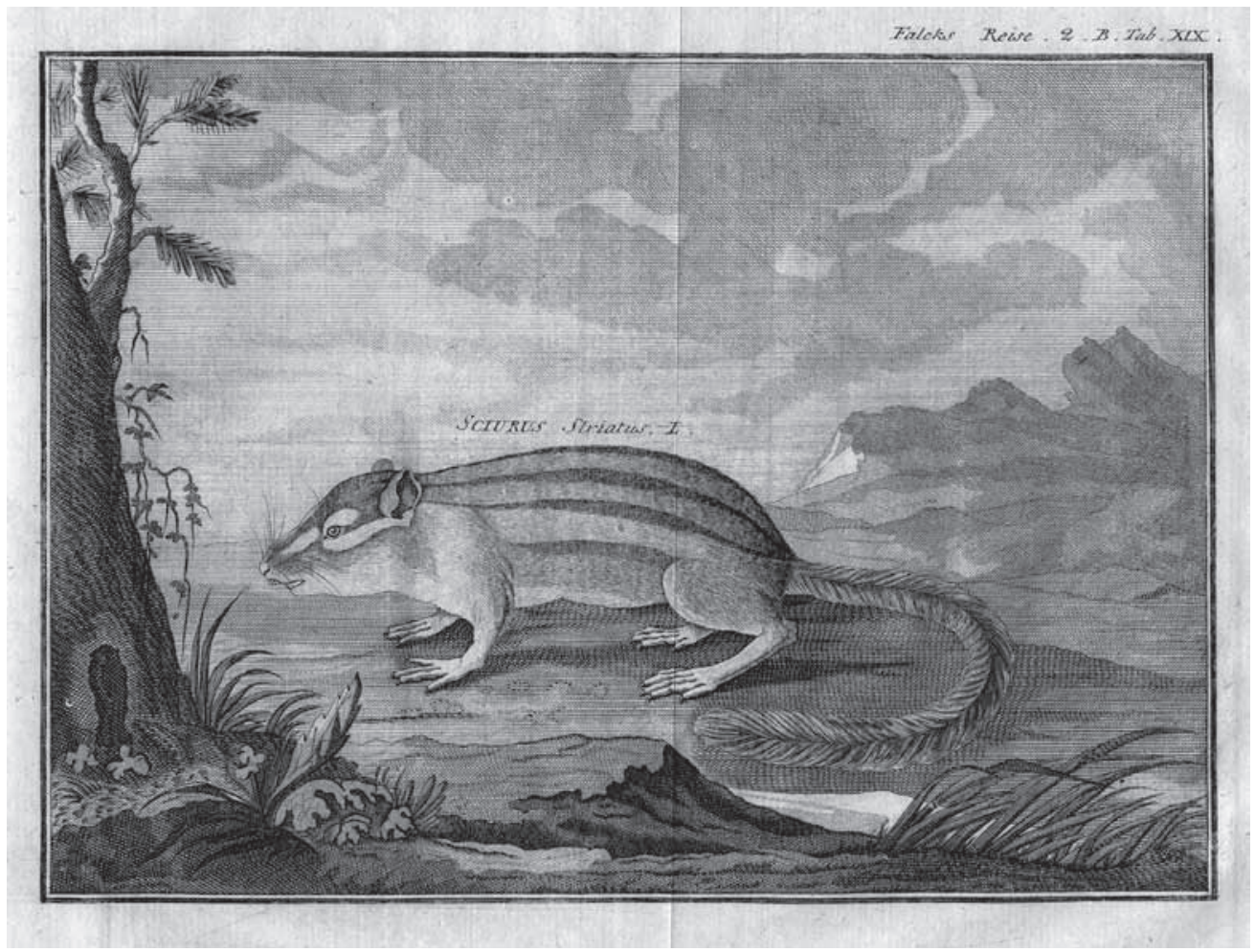

Figure I. Eastern chipmunk (Tamias striatus) (Falck I786).

common pets and fur animals in homes throughout Russia and Siberia (Falck 1786: 302; Georgi 1800: 1580-1581). Probably their easy domestication influenced the choice of marmots over other fur animals. Several Mongolian peoples used marmots, especially the tarbagan (Marmota sibirica) and black-capped marmot (Marmota camtschatica) for furs, meat and medical purposes (Badmaev et al. 2009).

The list of fur animals would not be complete without hares and rabbits. In Siberian homes, both wild and domesticated rabbits (Lepus cuniculus) were popular. Their popularity was mostly due to their furs, but also their meat was eaten. Being a pharmacist, Georgi was extremely careful about hygiene and noted that rabbits were terribly dirty when kept within the house (Georgi 1800: 1599; cf. Jusupov 1968: 194 on the hare among the Tatars and other Turkic peoples). A few steppe pika (Ochotona pusilla), which is similar to the common hare but smaller, accompanied Falck on his journey for several weeks. He fed them with seeds, herbs, roots, bread and milk, but their favourite foods were tulip bulbs and other wild roots. During the day they would not move and only at night did they eat, but in all other aspects they co-existed peacefully in their cage with other animals. Falck sent them to St. Petersburg, but they died on the way (Falck 1786: 301; Georgi 1800: 1600). 


\section{Pest controllers and other useful animals}

The habit of keeping wild animals in homes for pest control is known from different parts of the world (cf. Ståhlberg \& Svanberg, forthcoming). Houses and yurts were usually infested with many kinds of vermin such as mice, rats and insects. In Russia, Siberia and Central Asia house cats were common, but there were other possibilities to control vermin populations. Local peoples caught wild animals and kept them in houses, leaving them to feed on pests until the uninvited guests were destroyed or their numbers decreased to tolerable limits. Interestingly, there is only one wild relative of the domestic cat (Felis catus) in our records. Georgi (1800: 1523) mentions the Persian and Caucasian caracal (Caracal caracal). In Volga Tatar and several other Turkic languages it is called karakulak 'black ear'. It could be tamed if caught young and it performed the functions of a house cat (cf. Masetti 2009).

Instead of cats, in the Caucasus and Caspian areas it was common to catch young mongoose, probably Indian grey mongoose (Herpestes edwardsi), and keep them at home. The species is now extinct in these areas, but can still be found in remote regions of Iran, southern Iraq and Afghanistan (Harrison 1968). Erik Laxman (1737-1796), originally from Finland but working as a mining expert for the Russian government, kept one in his home in St. Petersburg. Laxman was very satisfied with this pet and pest controller, as it devoured rats and mice and was more efficient than an ordinary cat (Georgi 1800: 1526).

Cossacks in Siberia often had Daurian hedgehogs (Mesechinus dauuricus) at home for the same purpose. While efficient, they were dirty, stank and often ran away by digging a tunnel under the threshold (Georgi 1800: 1552; cf. Taube 1991). Falck (1786: 288-289) kept a hedgehog for several months in a cage. It was fed with mice, small birds and the viscera of birds prepared for conservation. "Easy to keep," wrote Falck, "but when it gets out of the cage it hides, and if the room is not tightly shut, it disappears." There were different opinions about the animal. Some of Falck's travel companions did not mind its smell, but others found it abominable. The Indian crested porcupine (Hystrix indica) was also kept in Russian homes for pest control. Its young adapted quickly to human settlements (Georgi 1800: 1554; cf. Dupree 1956).

Falck kept a couple of colourful marbled polecats (Vormela peregusna, Fig. 2) in a cage during his journey in the Volga region. Despite its name, this animal belongs to the Mustelidae family. Falck was told that during the day the wild polecat slept or kept to its burrow. At night it hunted hares and voles, plundered bird nests and even dared to enter chicken sheds in the villages. Falck's caged polecats were fed with meat and the innards of preserved birds. They ate well and seemed to thrive, but remained very ferocious (Falck 1786: 314). Polecats as pest controllers are known also from other parts of Asia. Afghan shopkeepers in the 1940s kept marbled polecats in their shops in order to exterminate rodents (Akhtar 1945).

Flying pests were caught and consumed by starlings (Sturnus vulgaris). This bird feeds on insects and is especially tough on locusts, but around human settlements it is often an omnivore. It was not kept at home but encouraged to live around houses. 


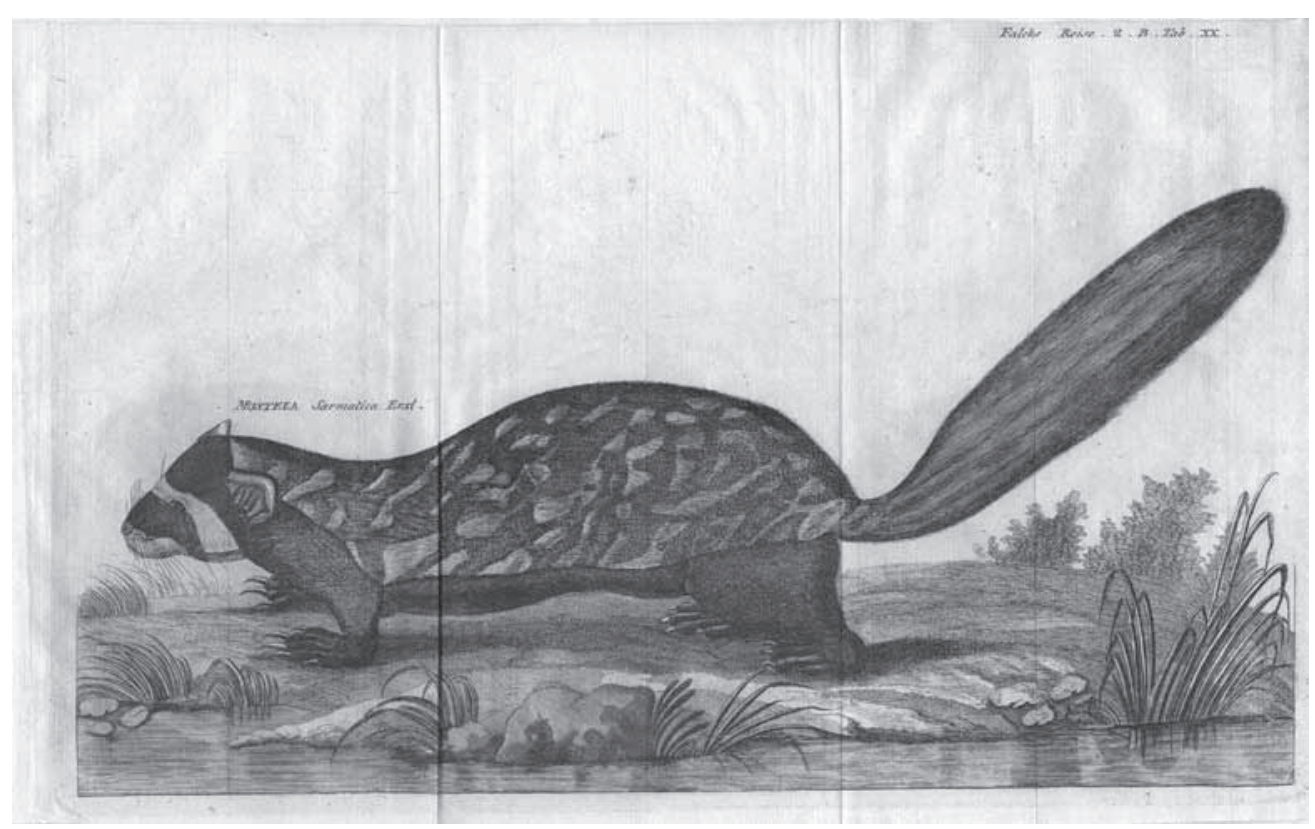

Figure 2. Marbled polecat (Vormela peregusna) (Falck 1786).

In southern Russia, people hung old pots and casseroles from the roofs so that the useful birds would stay and nest. In Bukhara and Khiva the starling enjoyed great respect, because it was believed to consume locusts which every few years destroyed crops in Central Asia and southern Siberia. Informants told Falck (1786: 393) that one could see the locust clouds diminish when the birds attacked. The locusts in turn would, according to popular belief, gnaw on the birds so that they lost their feathers and were unable to fly.

Vermin were also not uncommon as pets in Eurasia. The same animal could be both pest and pet depending on the circumstances. Rats and mice still today fulfil this double function of cellar or barn pest and cute cage animal. Uninvited, but present in all homes were rats (Rattus rattus) and house mice (Mus musculus). Russia, Siberia and Central Asia were infested with these rodents which lived mostly in cellars and in or around human settlements. The Ural Cossacks believed rats to have nearly human minds and had many proofs for this fact. Other peoples were not impressed when the rats gnawed on everything, clothes, furniture, food and the house in general (Falck 1786: 307; Georgi 1800: 1559). In eastern Siberia, also the grey rat (Rattus norvegicus caraco) infested houses, and all over Siberia the wood mouse (Apodemus sylvaticus) and house mouse destroyed crops.

Despite the destructive tendencies of these vermin, many peoples kept different kinds of mice at home. The Northern birch mouse (Sicista betulina) was easy to tame but sensitive to cold. A white house mouse was a popular pet both in Siberia 
and upper class homes in St. Petersburg (Georgi 1800: 1557, 1560-1561, 1564; cf. Clutton-Brock 1999: 109; see also Svanberg 2006: 133-138 for eighteenth-century Swedish examples). Other mice in human surroundings were the striped field-mouse (Apodemus agrarius), harvest mouse (Micromys minutus) and southern birch mouse (Sicista subtilis). These entered grain stores and were not always popular, but they were caught and played with (Falck 1786: 309).

One animal was kept as a pet and used for medicine. Especially tame and easy to keep was the great jerboa (Allactaga major), a rat-size jumping rodent from the southern fringes of Siberia and the Central Asian steppes. Falck kept a couple of jerboas in a cage for some months. They ate roots, fruit and fresh branches from trees, gnawing at the bark. They eventually became very fat and Falck sent them to St. Petersburg where they arrived alive. The Kazakhs and Barabin Tatars dried these jumping mice and ground them to powder, giving the medicine to women during difficult births (Falck 1786: 309-310; Georgi 1800: 1593).

\section{Entertainment}

Peasants and nomads were not the only keepers of wild animals in the eighteenth century. Town dwellers also longed for the company of animals. The differences between keeping animals in rural areas and towns included a larger distance to nature from the town dwellings, more limited possibilities to keep animals, questions of hygiene, living space and above all, the economy. Town dwellers had other means to survive and prosper such as trade, and were therefore less interested in keeping animals for economic reasons, food or furs. Their animals were mostly kept for entertainment. The richest urban citizens kept wild animals in parks or gardens for their own enjoyment and to show off to guests. The upper class in Russia commonly had parks with red deer (Cervus elaphus) in their country estates (Georgi 1800: 1609).

There were also many amateur scientists among the educated or rich. They sought to make observations and gather scientific information through experiments. A nobleman kept a couple of steppe fox (Canis corsac) in his garden in Moscow around 1770. He tried to make it cross-breed with an ordinary fox or a dog, but without success (Falck 1786: 324). A pond-turtle (Emys orbicularis) was observed by Falck (1786: 411) in Tsaritsyn (now Volgograd). It was common around the Don, Volga and Ural Rivers and in the Kazakh and other steppe lakes. The protopop (Russian npomonon) or archpriest of Tsaritsyn kept a few big turtles in his garden. They could go without food for fourteen days, becoming significantly lighter, but had to be watered and fed after that. The priest told Falck that he had seen turtles eat crabs on a beach by the Volga River. This is very possible, because the turtle feeds on invertebrates, amphibians and plants.

Animals were often trained or kept in chains as active entertainers. Georgi (1800: 1546) mentions a nobleman in St. Petersburg who kept two polar bears (Ursus maritimus) in chains which were long enough to enable the animals to swim in a pond. 
They wandered about in the courtyard to the pleasure of spectators and were fed with raw meat. Bears were trained by villagers and brought to towns where they earned money by providing entertainment for the public. In Russia and Poland, the brown bear (Ursus arctos) was caught and taught to dance by local people, acting as a kind of living animal show and a source of income for its owner (Georgi 1800: 1544). The tradition has lived on in Russia where dancing and skating bears became part of circus shows (now illegal in Europe). Some Roma in Anatolia and the Balkans keep bears as attractions to the present day, taking bear cubs and training them to make simple dancing steps (Berg 1968; Gunda 1989: 252-253; Svanberg 1994).

Birds continue to be the main entertainers among animals, both in number and distribution. The importance of animal music is reflected in science: songbirds formed a separate category of birds in the eighteenth century. They were kept only for amusement when most other birds were eaten or used as hunting assistants. All over Europe and Asia there were songbirds available in specialised bird markets (Robbins 2002; Kinzelbach 2004). In Russia, the greatest variety of songbirds was sold at the bird market in Moscow. Falck (1785: 53) described it as a large market with huge amounts of wild animals of all kinds: "It can be visited often and at different times, and one can see more variety here than one can hope to observe during any journey."

Among the songbirds sold in Moscow, Falck noted the Eurasian jay (Garrulus glandarius). This bird was common in nature from Moscow to Orenburg, in the steppe areas and western Siberia. Its capability to imitate other birds brought it into captivity and it was sold for an average of 40-50 kopeks in the market (Falck 1786: 336). The rose-coloured starling (Sturnus roseus), a pink-black bird from the lower Volga, was another caged singer which Falck (1786: 394-395) heard himself. The blackbird (Turdus merula), also heard by Falck, cost between 80 kopeks and 1.50 roubles, but trained blackbirds were expensive, 5-6 roubles. A similar price was set for the goldfinch (Carduelis carduelis), but the siskin (Carduelis spinus), which also sang beautifully, cost only 1 rouble (Falck 1786: 400). The "Swedish nightingale" or bluethroat (Luscinia svecica) was very popular in Moscow. At the cheap price of 15-40 kopeks the common crossbill (Loxia curvirostra) could be bought. It whistled and could be trained to imitate other birds (Falck 1786: 403, 396). This detail is interesting, because usually the crossbill is not known for the ability to imitate. Many of these songbirds - especially the goldfinch and siskin - have been popular as cage birds in northern and western Eurasia since at least medieval times (Gessner 1600: 56; Yapp 1982; Kinzelbach 2004; Svanberg 2008).

Singing was not the only reason that birds were kept at home. Solely for their beauty, golden oriole (Oriolus oriolus) males were caught and sold for 30 kopeks or more, but the uglier females did not exist on the market (Falck 1786: 337). Because of its stunning blue beak, the white-headed duck (Oxyura leucocephala) was a common house animal. It can hardly fly, so it keeps to a limited region in southern Siberia. When angry or afraid, or when humans touched it or a cat was present in the room, its impressive blue beak turned grey. The blue colour returned when the bird calmed down. When tamed, the bird became phlegmatic and was not easily scared (Falck 
1786: 349-350). The red-backed shrike (Lanius collurio) was kept as a kind of cruel entertainment provider in many homes from Moscow to western Siberia. With its strong beak the shrike captured smaller birds and tore them apart without killing them first. Falck heard that people kept the birds free-flying in the house with smaller birds just to see such hunting. He himself (1786: 333) kept a great grey shrike (Lanius excubitor) for several months in a cage, feeding it with meat and smaller birds. It was a lively and happy companion to the explorer who regularly suffered from illness and depression.

Two other birds, the pheasant and the chukar partridge, locally known as kakelik, were kept for amusement. The pheasant was also kept for meat in Bukhara, Khiva, the Caspian steppes and Chinese Central Asia. Pheasants are still popular decorative birds in gardens and cages in Europe and Asia. According to folk belief in Central Asia, the common pheasant (Phasianus colchicus) always walked the same path and could be easily caught with snares. In Bukhara it was a popular courtyard bird (Falck 1786: 387). Falck never saw the strange chukar partridge (Alectoris kakelik), but described it from hearsay and noted its strange call, kakelik, kakelik (Mlíkovský 2006). It was kept in cages in Bukhara (Falck 1786: 390; cf. Svanberg 2007b).

\section{Household and hunting birds}

Several birds were caught and used for food in Russia, Siberia and Central Asia. Before being consumed, they lived as pets or household birds in human settlements. Georgi (1799: 1024) observed that young wild geese and ducks of different species were taken in spring from their nests. When they were fat enough in the autumn, the birds were killed and eaten. New nestlings were taken again the next spring. This saved expenses, because there was no need to feed the birds during the winter and there was always the risk that they would not survive (Falck 1786: 344). However, some birds like the greater scaup (Aythya marila) could not thrive in houses or reproduce, or even become as beautiful as wild adults, despite human efforts to accommodate them (Pallas 1771: 169).

A common household bird was the swan goose (Anser cygnoides) which occurs in China but also around the $\mathrm{Ob}$ and Yenisei Rivers and in eastern Siberia. It was kept in or around many homes (Falck 1786: 339). The ruddy shelduck (Casarca ferruginea) and greylag goose (Anser anser) could be tamed if taken when young. Especially Cossacks and Russians either caught the ducklings or took the bird's eggs. Geese sat on the eggs for a month, but then wandered off and another bird had to be found to finish the brooding. These birds, according to Falck (1786: 343-344), could be good household birds because of their size and endurance, but they reproduced too slowly around humans and died out within two or three generations. The custom of raising wild ducklings and other sea birds at home is also described from Finland and northern Scandinavia (Wright 1857: 70-71; Storå 1968: 144; Svanberg \& Ægisson 2005). 
Animals as hunting assistants are mostly limited to birds in Central Asia (compare dogs, above). At least Kazakh, Mongol and Kalmyk nomads hunted with birds. Hunting with birds of prey (eagles, falcons, hawks) was widespread in the Eurasian steppes and is mentioned already by medieval travellers like William of Rubruck (Rubrouck 1997: 86). It is still practised in Mongolia, Kazakhstan and China as a pastime. Previously it was a hobby only for the noble and wealthy due to the costs and time involved (Le Coq 1913; Svanberg 1988; Simakov 1989). Among the most important hunting birds is the imperial eagle (Aquila melanaetus). This eagle is common around the Volga and the Ural and feeds on fox, hare, lamb, geese and other animals. Falck (1786: 326) saw one eagle which consumed about two kilograms of meat daily. The white-headed sea eagle (Haliaethus leucocephalus) was even more important for the prestige of the Kazakhs. It was very rare and called ak saltan 'white prince' by Kazakhs and Kalmyks. An eater of foxes and fierce fighter, this eagle was frequently bought by rich Kazakhs at the Russian-Kazakh border markets. They taught the bird to hunt, but noblemen would also use the wing quills like all eagle feathers for their arrows. When a Kalmyk saw the eagle flying, he made a deep bow, because in popular belief the Buddha had journeyed the world on the back of it (Falck 1786: 326-327).

South European golden eagles (Aquila chrysaethus fulva) were carried off as nestlings by the Bashkirs in the Ural region. They fed the birds until they were grown and then sold them to Russian and Tatar buyers who transported the eagles down to Kazakh border markets. Kazakh noblemen preferred this bird for hunting, training it and paying one good horse per bird and two or three horses for an already trained eagle. When an old bird was caught, it was not tied with a string like the more dangerous young hunter birds, even though it, according to Falck, "with visible pride" tore up a hare or any small animal. The trained bird hunted hares, foxes, antelopes and even pigs or wolves, sticking its long claws into their necks and eyes and holding the prey fast until the human hunters arrived. The Kazakh and Kalmyk nobility considered such hunting to be their greatest pastime (Falck 1786: 327). Also the steppe wolf was hunted with the help of this eagle (Georgi 1800: 1508). Golden eagle (Aquila chrysaëtus) nestlings were taken near Samara and sold for high prices to Kazakhs, who trained them to hunt (Pallas 1771: 213-214).

A more difficult bird to hunt with was the gyrfalcon (Falco gyrfalco) which existed previously in the Ural area. Rich Kazakhs trained it, but let it take down only other birds and falcons (Falck 1786: 331). A birkut, identified by Falck as a ringtailed eagle (Falco fulvus), posed the biggest risk. Skilled Kazakh hunters used to buy the bird in Orenburg for 6-7 roubles and train it to hunt. An already trained falcon cost two camels. However, if the owner was not extremely careful, he could be killed by the bird, of which Falck (1786: 546-547) had heard at least one example. The bird remained an active hunter for about ten years, which made it a good investment.

Among the birds of prey, the eagle owl (Bubo bubo) played a special role as a lucky bird for the Kazakhs. In Europe, the owl is often considered a harbinger of bad tidings, probably because it is nocturnal and has a hollow voice. However, Kazakh men brought it along on hunting trips and ordinary journeys, mainly for protection 
against magic and as a bringer of luck for the hunt. A legend tells that the brave hero (Kazakh batyr) Bay Tibet was defeated by a magician who turned him into an owl. This owl still complains about its misfortune but, at the same time, it brings luck to those who carry it (Falck 1786: 332; cf. Castagné 1930: 67; Boyle 1979).

\section{Uninvited guests}

Reptiles and insects enjoy some popularity as pets today, but in Russia, Siberia and Central Asia they were not welcome in homes or around human settlements. They were seen as pests or dangerous to have around, even the bees which were also considered useful. Folk tradition is rich in negative attitudes. An example from Central Asia is the agama (Phrynocephalus helioscopus), a lizard common in the Caspian and Kazakh steppes and Bukhara. The Bukharans believed it crept on sleeping humans and sucked blood until the victim was poisoned and died. Then the lizard had to be cut from the skin (Falck 1786: 413). Falck was less prejudiced against lizards and kept in his ambulatory zoo a green sand lizard (Lacerta agilis) in a large glass jar. It refused to eat even though Falck fed it with the kind of insects that he had observed wild lizards consume. When he let it go, out of compassion after it had starved for a month, it ran away quickly as if it had never gone hungry.

Insects form a special group of animals in human surroundings. There are of course useful insects such as bees, but most insects are still considered bad for humans. Only the honey-making bees were encouraged to live in certain places for the convenience of gathering their products. The Bashkirs were known as the best beekeepers, but also the Votyak (Udmurt) and Tatars around the Volga and near the Bashkirs had beehives in their courtyards. Tree trunks were hollowed for this purpose (Pallas 1776: 499; Falck 1786: 458; cf. Tryjarski 1970). Honeybees (Apis mellifera) in the Ural area were often wild or feral and some possibly originated from swarms lost by the Bashkirs. In the Kazakh steppe and its forests there were bees as well, but in Bukhara wild bees nested in trees. Their bite was considered so poisonous that humans refrained from taking honey from them (Falck 1786: 438).

Most other insects in human settlements are considered uninvited guests, but for centuries humans have co-existed with them. Some insects were both pests, pest controllers and pets (compare rats and mice). For instance, house crickets (Acheta domesticus) lived in the warm stove walls in Russia and parts of Siberia. They were pests, but people did not mind them. Crickets are popular pets in China and elsewhere in Asia (Falck 1786: 112).

Russian and Siberian houses were greatly infested with insects in the eighteenth century. In Saratov on the Volga, the new German colonists were very healthy and their recently built houses still free from cockroaches, but bedbugs (Cimex lectularius) invaded immediately. This was an insect that most people detested, and whole families had to move elsewhere in the summer because they could not endure them. They were combated with magic and practical methods. At Tara, a dead snake was put 
into the skull of a horse or other animal together with hot ashes and left for a long time in the house. The smell allegedly made the bedbugs disappear. Erik Laxman in Barnaul attested himself the effect of this technique which, however, lasted only for some time before the procedure had to be repeated. Another possibility was to collect the knight bug (Lygaeus equestris) which, according to folk belief, ate the smaller bedbugs. Sometimes the predators became almost as difficult to get rid of as the prey. Falck (1786: 112, 434-437) observed that if several knight bugs were put into a glass, they would devour each other. Also Pallas (1773: 425) mentioned that a certain kind of ant was encouraged to live in houses in western Siberia to clear out bedbugs. The consequences are not known.

Probably the most common animal in Eurasian homes was and still is the Oriental cockroach (Blatta orientalis). Cockroaches invaded especially wooden houses and the so-called "black cottages" or living, cooking and eating spaces ("white cottages" or rooms were for guests only), which were heated by means of a baking oven instead of a stove. Cockroaches lived in the moss insulation of the walls, in warm, dark corners and among fur clothes. They consumed "everything dirty that could be eaten", including fur and leather. Falck (1786: 434-435) was told that in the Bukharan steppes cockroaches were even more numerous than inside houses. Among several peoples such as the Udmurt, combinations of practical and magical methods similar to those for bedbugs were employed: the house would not be heated in winter and the people moved out, the walls were washed with herbal water and ceremonies performed (Popova 2005: 95).

Sometimes even a zoologist can become tired of animals. "When I lived for more than fourteen days in a house," Falck wrote (1786: 434-435), "the cockroaches would occupy it almost completely." He decided on an experiment, putting breadcrumbs on benches and closing the windows so that the room fell dark. Then he sent the locals into the room armed with a candle and a small wooden plank, a shoe or another flat object. They found the benches covered with cockroaches and could kill many in one blow, though naturally most insects fled. When breadcrumbs were again strewn about, they returned. After a couple of days of such massacres there were no cockroaches left in the cottage, a fact which caused some upheaval among the inhabitants. Falck was not aware of the fact that his hosts, like many other Russians, believed that the disappearance of the cockroaches was a sign of bad luck. After a few cultural clashes Falck resorted to keeping lights burning during the night. This kept the cockroaches away and he found that the candles standing before the Orthodox icons fulfilled the same purpose.

Russians generally thought that the German cockroach (Blattela germanica) arrived from Prussia with the returning army during one of the wars of the eighteenth century. Falck and several other zoologists pointed out that it was an Asiatic insect which had wandered westwards from China, possibly with trade caravans. Such invading insects are not uncommon and there are several historical and modern examples. Today we have, for instance, the tiger mosquito (Aedes (Stegomyia) albopictus) and the well-known ticks (Ixodida) which have spread throughout Europe. The German 
cockroach is a very troublesome inhabitant in human settlements. It reproduces rapidly, eats up the house, clothes and food and spreads filth. Falck (1786: 435-436) was shocked about the lack of hygiene and the amount of cockroaches in food during his travels in Siberia. "Many people do not worry about filth in food and eat with a good appetite," he wrote. Yet when the prussak (Russian пруссак) grew too large in number, people reacted. In cold winter days, the house was left open until most of the insects died, but some cockroaches always survived in the wooden cottages. According to popular belief, cleaning the house and various magical methods helped, as did smoking tobacco.

The poisonous wolf spider (Lycosa singoriensis) was a real threat to human well-being. It was common in the southern regions, especially the steppe area and around settlements. According to Falck (1786: 443-444), his informants said that sheep liked the spider for food, so it avoided them and anything that had to do with sheep. The local peoples therefore slept on sheep pelts or with sheep wool blankets. When the spider bites, the skin becomes irritated. According to popular belief, if the bite was not cured with magic, sucking the poison out or burning with a hot iron, the patient faced certain death. The wound could also be covered with crushed wolf spiders or sour milk in which the spider had been dipped. Several Kalmyk said, however, that the wolf spider was not especially dangerous. Falck's friend, a certain doctor Wier in the German colony of Sarepta, experimented by putting five wolf spiders on a slice of bread and feeding them to a dog, which did not show any reaction. Then he put five small spiders in a jar with one large spider which consumed the little ones. Falck received two large spiders as a gift and they fought in his glass jar until one of them lost and was devoured. He then put live flies in the jar, but the spider would not touch them until they were dead. Then it sucked them out so that only the shell was left. Another large spider Falck received in Syzran carried about sixty small ones on its back. When the jar stood in the shadow they were calm, but in the sun when it became too hot, the small ones fell off and the mother became agitated. When Falck threw a handful of sand into the glass, she tried to hide in it without success.

\section{Parasites}

Nowadays in developed countries people tend to forget that previously - and in many regions of the world to this day - humans involuntarily keep many animals on or inside their bodies. It is important to discuss this topic, even though it is not an especially agreeable one. Parasites are probably the only animals except insects and reptiles that humans fear or avoid. They belong to the category of vermin in the human environment, but they can simultaneously and somewhat ironically be classified as the animals closest to humans. Some are transmitted from human to human, while others are contracted from the outside world. In eighteenth-century Russia and Siberia, parasites were not considered as terrible as today and some where even encouraged to live on humans. 
One of the most common parasites on humans is the head-louse (Pediculus humanus captitis). Falck (1786: 439, 570) observed that it was very common among the Russians and poor Tatars in Russia and Siberia, but from the middle class upwards prosperous Tatars were spared. Regular bathing and thin hair growth were identified as the main reasons. Personal hygiene was not important for most people in the countryside, but in towns and among Volga Tatars bathing was common. The Kalmyks, Ostyaks and other poor peoples also carried this insect in their clothes. Falck observed that their clothes and furs were alive with insects. Probably he meant the body louse (Pediculus humanus humanus or corporis). Also pubic lice (Phtirus pubis) were very common.

An animal that has nearly disappeared in Central Asia but which thrives in the human body is the Guinea worm (Drancunculus medinensis). It was erroneously identified by Falck and others as the harmless Gordius aquaticus. Such a misidentification was made already by Linnaeus (1746: 363). As a trained medical doctor, Falck (1786: 446-447) was interested in all kinds of illnesses and received in western Siberia a Guinea worm which was $50-60 \mathrm{~cm}$ long. Falck cut it up in six pieces and the segments lived independently for several days in a jar filled with river water. When he added salt the segments died very soon. The Guinea worm lives on river beaches and was a common parasite for centuries in various parts of Southern Europe, Asia and Africa. In Central Asia it was common until the 1930s, when it was exterminated. The species is now rare except in parts of Sub-Saharan Africa (Ashford \& Crewe 1998: 76). A Bukharan interviewed by Falck (1786: 447) told that he had seen the worm even in a person's eye and in babies and that sometimes people had several worms in their bodies. The worm was taken in with drinking water from the river. When the worm's head appeared through the skin, it was wound around a stick. About $2-3 \mathrm{~cm}$ of the worm came out every day and the healing procedure took a long time. Some people held several worms in their bodies and had to undertake the painful process of slowly pulling them out ten or even more times during their lifetime.

Finally we should mention a useful parasite known also in traditional medicine in northern Europe: the medicinal leech (Hirudo medicinalis). The Russians, Tatars, Armenians and many others filled old pots with leeches and water. Falck (1786: 447) observed a local "quack doctor" in the Siberian town of Barnaul preparing these animals. When the water froze, he let the leeches freeze with it. When he needed the animals he took up as many as required. The frozen medicinal leech sucked better than those that lived in marsh water in a warm room and moved around all winter. Leeches were used for medicinal purposes just as they are used today in Russia, Finland and many other regions (Linnaeus 1764; Whitaker et al. 2004). 


\section{Conclusion}

We can discern a long history of keeping wild animals for various purposes and reasons in and around human dwellings in Russia, Siberia and Central Asia. Economic reasons dictated in some way or another most of the human-animal relationships. Fur and free-roaming animals formed the largest part of the income and subsistence for the rural population and provided means for survival for nomads and peasants. Not only the local peoples, but also Russians and other immigrants kept these animals. Furthermore, the human desire or need for animal company, an active interest and close relationship with the surrounding wildlife and the challenge, especially for men, to domesticate wild animals or hunt with their assistance, can be identified as additional motivations for catching and keeping animals.

Some animals were left to roam freely in the forest or steppe. These were large mammals with mainly economic purposes such as horses, sheep, reindeer and cattle. They existed in great numbers and were used for food, drink, hides and clothes, as prey when hunting, and for riding, pulling and carrying items and people or even yurts. They were multi-purpose animals which could survive without much effort or care from humans, who despite the distance claimed property rights over them.

Smaller mammals were mostly kept as pets and fur animals. The two functions were usually combined in one animal. Furs formed a considerable part of the most developed and broadest trade in Russia and Siberia and were part of the tax system. Furs were also exported to other countries, a practice which travellers like Marco Polo and Ibn Battuta attested already in the thirteenth century (cf. Martin 2004: 30; Lincoln 2007: 60). It was often easier to keep a couple of fur animals at home and fatten them up than to hunt. They could provide company and pets for the children as well. Many of the animals killed for furs were kept as pets when small, in spite of the consequences such as dirt, smell and destruction of furniture, food and clothes. Some of the smaller predatory mammals were also used as a kind of pest control against rats and mice.

Urban residents and noblemen in Russia often owned gardens and parks with wild animals. These animals were kept only for entertainment, like songbirds which were commonly bought in cities for their beauty or their voices. A singing bird was as pleasant to peasants in Siberia as it was to Carl Linnaeus in Uppsala or a professor or nobleman in St. Petersburg (cf. Svanberg 2007a). Nomads kept mainly hunting birds, falcons, eagles and hawks, but this was an entertainment limited to the rich. The European habit of keeping birds in houses as pest control is nowhere mentioned and we do not know if this efficient method of keeping vermin under control existed in Russia and Siberia (Ståhlberg \& Svanberg, forthcoming).

The insects in and around human dwellings were mostly unwanted, but sometimes they could be played against one another. Supposedly also wild birds and other animals entered houses and yurts in summer when the doors and windows or smoke holes were open. These animals were probably not kept as pets, but left to come and go freely. In and on human bodies parasites thrived, mostly unwanted, but if not seri- 
ously disturbing, the local peoples in Russia, Siberia and Central Asia did not greatly mind, accepting their presence as normal.

Our knowledge about companion animals, domestic animals and other animals in close relationship with human beings in older times is scant. In this study we show that several common and also unusual wild species were kept in captivity in houses in Russia and Siberia. Several other species were feral or not tame and roamed freely in Siberia and Central Asia until the nineteenth century, when the growing human population limited and destroyed their habitats and through hunting diminished their numbers. The task of the explorers from the Imperial Academy in St. Petersburg was to observe, describe and analyse all animals they could find. When they returned (or in the case of Falck, died on the road) they had few successors who would be interested in the aspects of free-roaming domestic animals and domesticated wild animals. Not until the German zoologist Alfred Brehm undertook a journey to Central Asia and southern Siberia in the 1870s did the focus on relations between humans and animals receive renewed attention (Brehm 1982).

Today, various wild birds and mammals are kept as pets in urban and rural surroundings in Eastern Europe, Russia, Siberia and Central Asia, e.g. the chukar partridge and hunting eagles, but there has still been little research on the subject. This study can hopefully serve as a basis for further research. It is further important to study the practice of keeping wild or feral animals from a religious, ritual and conceptual point of view (cf. Ilomäki \& Lauhakangas 2002). Magic, beliefs and traditions played a significant role in the relationship between humans and animals. For the protection and prosperity of the animals humans performed certain actions. These traditions require a deeper analysis and could yield much new information.

Another important aspect for study is the diet and the influence of religion, traditions and local ecological knowledge on the human-animal relationship. Among the Kalmyk, devout Buddhists who believed in reincarnation would not kill any animal. They even picked up lice and put them back into their fur clothes. Many believers also bought live animals which were on sale for meat and set them free, and consumed only animals that had died from a natural cause. In Tsaritsyn (now Volgograd) several cattle owners had fixed prices for such animals, knowing that the Kalmyk would buy the carcasses (Falck 1786: 570).

Gender questions should also be taken into consideration, as male and female social roles especially among nomads were clearly distinguished and influenced their relationship with animals. Among the Kazakhs, for example, the men were responsible for the herds in general but women milked the animals, cooked food and took care of most other tasks in animal-keeping (Falck 1786: 574). Traditions concerning butchering, preparation of food, hides and skins and the sacrifice of animals, as well as concepts and attitudes relating to these practices also require further study. The analysis of local ecological knowledge, which is a dynamic complex of information and data about the natural environment, is needed to illustrate the human-animal relationships in Russia, Siberia and Central Asia. Future research will hopefully focus on this important issue and bring forth more information and new perspectives. 


\section{References}

Akhtar, S. A. 1945: On the habits of the marbled polecat, Vormela peregusna. - Journal of Bombay Natural History Society 45: 142.

Ashford, R. W. \& Crewe, Wilhelm 1998: The parasites of Homo sapiens: an annotated checklist of the Protozoa, Helminths and Arthropods for which we are home. Liverpool: School of Tropical Medicine.

Badmaev = Бадмаев, Б. Б., Раднаева, Л. Д. \& Павлов, И. А. 2009: О медико-биологической основе использования жира сурка в Забайкалье и Монголии. - Натуротерапия 16: 30-34.

Berg, Gösta 1968: Zahme Bären, Tanzbären und Bärenführer. - Der Zoologische Garten 35: $37-53$.

Berg, L. S. 1954: Geschichte der russischen geographischen Entdeckungen. Gesammelte Aufsätze. Leipzig: Bibliographisches Institut.

Bonnemaire, Joseph 1984: Yak. - Ian L. Mason (ed.), Evolution of domesticated animals. London: Longman. 39-45.

Boyle, J. A. 1979: The owl and the hare in the popular beliefs of the mediaeval Mongols. Central Asiatic Journal 23: 65-71.

Brehm, Alfred 1982: Reise zu den Kirgisen. Aus dem Sibirientagebuch 1876. Leipzig: Reclam.

Broberg, Gunnar 1971: Järven-Filfrassen-Frossaren: en studie i zoologisk exotism. - Lychnos Arsbok. 181-216.

Brusewitz, Gunnar 2001: De hjälpsamma djuren. - B. Pettersson, I. Svanberg \& H. Tunón (eds), Människan i naturen: etnobiologi i Sverige 1. Stockholm: Wahlström \& Widstrand. 119-126.

Castagné, Joseph 1930: Magie et excorcisme chez les Kazak-Kirghizes et autres peoples turcs orientaux. - Revue des études islamiques 4: 54-151.

Clark, Bill \& Duncan, Patrick 1992: Asian Wild Asses - Hemiones and Kiangs (E. hemionus Pallas and E. kiang Moorcroft). - P. Duncan (ed.), Zebras, asses, and horses. An action plan for the conservation of wild Equids. Gland: IUCN/SSC Equid Specialist Group. $17-21$.

Clutton-Brock, Juliet 1999: A natural history of domesticate mammals. Cambridge: Cambridge University Press.

Drews, Carlos 2001: Wild animals and other pets kept in Costa Rican households: incidence, species and numbers. - Society \& Animals 9 (2): 107-126.

Dupree, Louis 1956: Note on the distribution of the Indian Crested Porcupine Hystrix indica. - Journal of Mammalogy 37: 299-300.

Erikson, Philippe 2000: The social significance of pet-keeping among Amazonian Indians. Anthony L. Podberscek et al. (eds), Companion animals and us: exploring the relationship between people and pets. Cambridge: Cambridge University Press. 7-26.

Falck $=$ Falk, J. P. (Johan Peter) 1785: Beyträge zur topographischen Kenntnis des Russischen Reichs. Teil I. St. Petersburg: Kayserl. Academie der Wissenschaften.

Falck= Falk, J. P. 1786: Beyträge zur topographischen Kenntnis des Russischen Reichs. Vol. III. St. Petersburg: Kayserl. Academie der Wissenschaften.

Georgi, J. G. (Johann Gottlieb) 1776: Beschreibung aller Nationen des Russischen Reichs. Vol. I. St. Petersburg: Carl Willhelm Müller. 
Georgi, J. G. 1799: Geographisch-physikalische und naturhistorische Beschreibung des Russischen Reichs. Vol. II. Königsberg: Friedrich Nicolovius.

Georgi, J. G. 1800: Geographisch-physikalische und naturhistorische Beschreibung des Russischen Reichs. Vol. III. Königsberg: Friedrich Nicolovius.

Gessner, Conrad 1600: Vogelbuch oder Aussführliche beschreibung vnd lebendiga ja auch eygentliche Controfactur vnd Abmahlung aller vnd jeder Vögel. Frankfurt am Main: Johann Saurn.

Gilmore, Raymond M. 1950: Fauna and ethnozoology of South America. - Julian Steward (ed.), Handbook of South American Indians 6. Washington DC: Government Printing Office. 345-463.

Gmelin, Samuel Georg 1770: Reise durch Russland zur untersuchung der drey Natur-Reiche. St. Petersburg: Kayserl. Academie der Wissenschaften.

Grier, Katherine C. 2006: Pets in America: a history. Chapel Hill: University of North Carolina Press.

Grubb, Peter 2005: Order Perissodactyla: Equidae. - Don E. Wilson \& DeeAnn M. Reeder (eds), Mammal species of the world. A taxonomic and geographic reference. Baltimore: John Hopkins University Press. 629-633.

Gunda, Béla 1969: Die Jagd und Domestikation des Kranichs bei den Ungarn. - Anthropos 63-64: 473-496.

Gunda, Béla 1989: A rostaforgató asszony. Budapest: Múzsák Közművelődési Kiadó.

Hare, John 1997: The wild Bactrian camel Camelus bactrianus ferus in China: the need for urgent action. - Oryx 31: 45-48.

Harrison, David L. 1968: The large mammals in Arabia. - Oryx 9: 357-363.

Hornstedt, Carl Fredrik 2008: Brev från Batavia: en resa till Ostindien 1782-1786. Stockholm: Atlantis.

Ilomäki, Henni \& Lauhakangas, Outi (eds) 2002: Eläin mielenmaisemassa. Suomalaisen Kirjallisuuden Seuran toimituksia 885. Helsinki: Suomalaisen Kirjallisuuden Seura.

Jonsson, Leif 2001: De första jägarna. - B. Pettersson, I. Svanberg \& H. Tunón (eds), Människan i naturen: etnobiologi i Sverige 1. Stockholm: Wahlström \& Widstrand. 100-106.

Jusupov, G. V. 1968: Survivals of totemism in the ancestor cult of the Kazan Tatars. - V. Diószegi (ed.), Popular beliefs and folklore tradition in Siberia. The Hague: Mouton. 193204.

Kinzelbach, Ragnar 2004: The distribution of the Serin (Serinus serinus L., 1766) in the 16th century. - Journal für Ornithologie 145: 177-187.

Kroeber, Alfred L. 1941: Culture element distributions XV: Salt, dogs, tobacco. - Anthropological Records 6: 1-20.

Kruse, Corwin R. 2002: Social animals: animal studies and sociology. - Society \& Animals 10: $375-379$.

Layton, Lesley 1991: Songbirds in Singapore: the growth of a pastime. New York: Oxford University Press.

LeCoq, Albert von 1913: Bemerkungen über türkischen Falknerei. - Baessler-Archiv 1913: $3-6$.

Lincoln, W. Bruce 2007: The conquest of a continent: Siberia and the Russians. Ithaca, NY: Cornell University Press.

Lindin, Leif \& Svanberg, Ingvar 1986: Traditional reindeer husbandry among the Evens of Kamchatka in the beginning of the 1920's. - H. Beach (ed.), Contributions to Circumpolar studies. Uppsala: Department of Cultural Anthropology. 
Linnaeus, Carl 1740: Beskrifning på Snö-Sparfwen. - Kongl. Swenska Wetenskaps Academiens Handlingar 1: 362-368.

Linnaeus, Carl 1746: Fauna svecica. Stockholm: L. Salvius.

Linnaeus, Carl 1754a: De mure indico. Uppsala: Höjer.

Linnaeus, Carl 1754b: Markattan Diana. - Kongl. Svenska Vetenskaps-Academiens Handlingar 15: 210-217.

Linnaeus, Carl 1764: De hirudine. Uppsala.

Linnaeus, Carl 1768: Mus Aguti, Eller Beskrifning på et Brasiliskt Djur, Aguti. Kungl. Svenska Vetenskapsakademiens Handlingar 29: 26-30.

Martin, Janet 2004: Treasure of the Land of Darkness: the fur trade and its significance for medieval Russia. Cambridge: Cambridge University Press.

Masetti, Marco 2009: Pictorial evidence from medieval Italy of cheetahs and caracals, and their use in hunting. - Archives of natural history 36 (1): 37-47.

Menges, Karl 1935: Die Wörter für ,Kamel' und einige seiner Kreuzungsformen im Türkischen. - Ungarische Jahrbücher 15: 517- 528.

Mlíkovský, Jiř́i 2006: Nomenclatural and taxonomic status of birds described by Johan Peter Falck in 1786. - Časopis Národního muzea, Řada př́rodovědná 175 (1-2): 17-25.

Moore, Clifford Bennet 1937: The book of wild pets: being a discussion on the care and feeding of our native wildlife in captivity. New York: Charles T. Branford.

Nellemann, George 1961: Theories on reindeer breeding. - Folk 3: 91-103.

Newsom, Lee A. \& Wing, Elizabeth S. 2004: On land and sea: Native American uses of biological resources in the West Indies. Tuscaloosa: University of Alabama Press.

Osbeck, Pehr 1757: Dagbok Öfwer en Ostindisk Resa Aren 1750, 1751, 1752. Stockholm: Lor. Ludv. Grefing.

Osipov = Осипов, Ю. С. 1999: Академия наук в истории Российского государства. Москва: Наука.

Pallas, P. S. (Peter Simon) 1771: Reise durch verschieden Provinzen des Russischen Reichs. Teil I. St. Petersburg: Kayserl. Academie der Wissenschaften.

Pallas, P. S. 1773: Reise durch verschieden Provinzen des Russischen Reichs. Teil II. St. Petersburg: Kayserl. Academie der Wissenschaften.

Pallas, P. S. 1776: Reise durch verschieden Provinzen des Russischen Reichs. Teil III. St. Petersburg: Kayserl. Academie der Wissenschaften.

Popova, J. V. 2005: Puhtaus. - Ildikó Lehtinen (ed.), Marit, mordvalaiset ja udmurtit. Perinteisen kulttuurin tietosanakirja. Suomalaisen Kirjallisuuden Seuran toimituksia 989. Helsinki: Suomalaisen Kirjallisuuden Seura.

Przheval'skii, N. M. 1876: Mongolia, the Tangut Country, and the solitudes of Northern Tibet London: S. Low, Marston, Searle and Rivington.

Rea, Amadea M. 2007: Wings in the desert: a folk ornithology of the Northern Pimans. Tucson: University of Arizona Press.

Robbins, Louise E. 2002: Elephant slaves and pampered parrots: exotic animals in eighteenth-century Paris. Baltimore: Johns Hopkins University Press.

Roth, Harald H. \& Merz, Günter 1996: Wildlife resources: a global account of economic use. Berlin: Springer-Verlag.

Rubrouck, Guillaume de 1997: Voyage dans l'Empire Mongol 1255-1255. Paris: Imprimérie Nationale Éditions.

Schiltberger, Johannes 1879: The bondage and travels of Johannes Schiltberger. London: Haklyut Society. 
Serpell, James 1989: Pet-keeping and animal domestication: a reappraisal. - J. Clutton-Brock (ed.), The walking larder: patterns of domestication, pastoralism, and predation. London: Unwin Hyman. 10-21.

Serpell, James 1996: In the company of animals: a study of human-animal relationship. Cambridge: Cambridge University Press.

Simakov, Georgii N. 1989: Hunting with raptors in Central Asia and Kazakhstan. - G. Seaman (ed.), Ecology and empire: nomads in the cultural evolution of the world. Los Angeles: Center for Visual Anthropology, University of Southern California. 129-133.

Sinor, Denis 1972: Horse and pasture in Inner Asian history. - Oriens Extremus 19 (1-2): 171-183.

Ståhlberg, Sabira 1996: Der Gansu-Korridor: Barbarenland diesseits und jenseits der Grossen Chinesischen Mauer. Hamburg: Dr Kovac.

Ståhlberg, Sabira \& Svanberg, Ingvar 2006: Sarana in Eurasian folk botany. - Journal de la Société Finno-Ougrienne 91: 133-157.

Ståhlberg, Sabira \& Svanberg, Ingvar (forthcoming): Keeping birds as pest control. - Ingvar Svanberg (ed.), History of Aviculture. Hancock House.

Storå, Nils 1968. Massfångst av sjöfågel i Nordeurasien. Åbo: Åbo Akademi.

Svanberg, Ingvar 1987: Turkic ethnobotany and ethnozoology as recorded by Johan Peter Falck. - Svenska Linnésällskapets Arsskrift 1986-1987: 53-118.

Svanberg, Ingvar 1988: The nomadism of Orta Zhüz Kazaks in Xinjiang 1911-1949. L. Benson \& I. Svanberg (eds) The Kazaks of China: essays on an ethnic minority. Uppsala: Almqvist \& Wiksell International.

Svanberg, Ingvar 1994: Björnföraren och bödeln: Om zigenare och zigenarliknande grupper i Grekland och Turkiet. - C. Camara \& H. Persson (eds), Möten med zigenare i Europa. Stockholm: Fjärde världen.

Svanberg, Ingvar 2000: Sminkrot (Lithospermum arvense) som färgväxt? Om några etnobiologiska uppgifter hos Linné. - Rig 84: 77-87.

Svanberg, Ingvar 2001: Siskeburar och guldfiskskålar: ur sällskapsdjurens kulturhistoria. Stockholm: Arena.

Svanberg, Ingvar 2006: Linneaner: Carl von Linnés lärjungar i Sverige. Stockholm: Wahlström \& Widstrand.

Svanberg, Ingvar 2007a: »Deras mistande rör mig så hierteligen«. Linné och hans sällskapsdjur. - Svenska Linnésällskapsets Arsskrift 2007: 11-108.

Svanberg, Ingvar 2007b: Orren på Mummens värdshus. Spelfåglar i 1700-talets Sverige. Rig 90: 82-86.

Svanberg, Ingvar 2008: Kammarsångare och rolighetsministrar. - J. Christensson (ed.), Signums svenska kulturhistoria 7. Det moderna genombrottet. Stockholm: Signum. 311342.

Svanberg, Ingvar \& Ægisson, Sigurður 2005: Black Guillemot (Cepphus grylle) in North European folk ornithology. - Scripta Islandica 56: 101-114.

Taube, Erika 1991: Der Igel in der Mythologie altaischer Völker. - B. Brendemoen (ed.), Altaica Osloensia. Oslo: Universitetsforlaget. 339-354.

Thomas, Keith 1983: Man and the natural world: changing attitudes in England 1500-1800. Oxford: Oxford University Press.

Tryjarski, Edward 1970: Beekeeping among the Turks: a historical and linguistic evidence. Acta orientalia 32: 241-267.

Van Gelder, Richard G. 1969. Biology of mammals. New York: Scribner. 
Way, Twigs 2008: A crocodile in the fernery: an $A-Z$ of animals in the garden. Stroud: Sutton.

Whitaker, I. S., Rao, J., Izadi, D. \& Butler, P. E. 2004: Ancient origin of, and trends in the use of medicinal leeches throughout history. - British Journal of Oral and Maxillofacial Surgery 42: 133-137.

Wright, Magnus von 1857: Anteckningar under en ornithologisk resa från Kuopio till Aavasaksa om sommaren 1856. - Bidrag till Finlands naturkännedom, etnografi och statistik 2. Helsingfors: Vetenskapssocieteten. 53-80.

Yapp, W. Brunsdon 1982: Birds in captivity in the Middle Ages. - Archives of Natural History 10: 479-500.

Yi, Fu-Tuan 1984: Dominance and affection: the making of pets. New Haven: Yale University Press.

Sabira Ståhlberg <http://www.sabirien.net>

Ingvar Svanberg <ingvar.svanberg@ucrs.uu.se> 